\title{
A voz-práxis estético-literária indígena como ativismo e militância: algumas reflexões a partir da literatura indígena brasileira atual
}

\section{The Indian aesthetic-literary voice-praxis as activism and militancy: some arguments from current Brazilian Indian literature}

Doutor em Filosofia (PUCRS). Professor de Filosofia e de Sociologia na Fundaçao Universidade Federal de Rondônia (UNIR). (i) https://orcid.org/0000-0002-2332-318 E-mail.leno_danner@yahoo.com.b Doutoranda em Teoria Literária pelo Programa de sidade Católica do Rio Grande do Sul (PUCRS). Mestre em Estudos Literários e graduada em Letras - Português e suas respectivas Literaturas pela Universidade Federal de Rondônia (UNIR). hittps://orcid.org/0000-0002-5428-2432 E-mail: juliedorrico@gmail.com

Doutor em Filosofia (PUCRS). Professor de Filosofia no Departamento de Filosofia da Universida-

(ii) https://orcid.org/0000-0002-4541-1204 E-mail: fernando danner@gmail
Leno Francisco Danner Departamento de Filosofia Fundação Universidade Federal de Rondônia. Porto Velho, RO Brasil. Julie Stéfane Dorrico Peres ${ }^{2}$ Programa de Pós-Graduação em Letras, Escola de Humanidades, Pontifícia Universidade Católica Fernando Danner ${ }^{3}$ Departamento de Filosofia, Fundação Universidade Federal de Rondônia. Porto Velho, RO, Brasil.

RESUM0: Defendemos que a voz-práxis estético-literária das minorias e, no caso, do/as intelectuais ou escritores/as indígenas é marcada por quatro características fundamentais que lhe definem a constituição, o sentido e a vinculação epistemológico-políticos: parte da condição política e politizante, carnal e vinculada das e como minorias, que são uma construção política, tanto em termos de singularidade antropológica quanto sob a forma de exclusão, silenciamento, marginalização e violência que sofrem; possui uma ligação e uma dependência inextricáveis entre comunidadegrupo-tradição e indivíduo, fundando e dinamizando um eu-nós lírico-político que não dissocia pertença à comunidade e ao grupo relativamente à experiência individual, recusando, com isso, a perspectiva de uma subjetividade absoluta-desvinculada e voyeurista-apolítica; vai da afirmação da tradição comunitária e da singularidade antropológica à crítica do presente, a tradição e a pertença comunitárias e a singularidade antropológica como crítica do presente; e institui o ativismo e a militância como seu núcleo, sentido e direcionamento, de modo a afirmar-se como uma vozpráxis política comprometida com a defesa e a promoção do grupo de que faz parte. Em nossa proposta, que está embasada tanto na interpretação de escritores/as indígenas brasileiros/as quanto na apropriação do aparato teórico produzido em termos de estudos literários e culturais póscoloniais, e que tem por base uma análise bibliográfica desse arcabouço teórico, argumentaremos acerca da importância de se correlacionar a produção estético-literária das minorias (e, no caso, dos/as indígenas) com e como crítica do presente e politização radical, sob a forma de ativismo, de militância e de engajamento, seja como condição para o entendimento de suas especificidades e novidades, seja como forma de sua vinculação aos debates estéticos, epistemológicos e políticos em termos de esfera pública, uma vez que esses/as escritores/as de minorias (e, no caso, indígenas) objetivam exatamente politizar e publicizar a história, a situação e as reivindicações de suas comunidades e de seus grupos por meio da arte-literatura.

Palavras-chave: Literatura indígena; Literatura de minorias; Comunidade-Indivíduo; Ativismo; Militância. 
ABSTRACT: We argue that the aesthetical-literary voice-praxis of minorities and, in our case here, of Indian intelectuals or writers is marked by four fundamental characteristics that define its epistemological-political constitution, sense and linking, namely: it starts from the political and politicizing, carnal and belonging of/as minorities, who are a political construction both in terms of anthropological singularity and relatively to exclusion, silencing, marginalization and violence which they suffer as minorities; it has an inextricable linking and dependence between communitygroup-tradition and individual, grounding and streamlining a lyrical-political I-We which does not dissociate the belonging to community-group and the individual experience, refusing, therefore, the perspective of an absolute-unlinked, voyeuristic-apolitical subjectivity; it starts from the affirmation of the communitarian tradition and the anthropological singularity and goes to the critic of the present, the communitarian tradition and belonging and the anthropological singularity as critic of the present; and it institutes the activism and militancy as its core, sense and direction, so that affirming itself as a political voice-praxis, compromised with the defense and promotion of the group of which it is part. In our proposal, which is based both on the interpretation of Brazilian Indian writers and in the literary and cultural post-colonial studies, and which is streamlined by a bibliographical analysis of this theoretical framework, we will argue about the importance of correlating the aesthetical-literary produciton of minorities (and, in our case, of Indians) with and as criticism of the present and radical politicization, in terms of ativism, militancy and engagement, both as condition for the understanding of its specificities and innovation, and as way for its linking to aesthetical, epistemological and political debates in terms of public sphere, since these writers of minorities (and, in the case, the Indians) aim exactly to politicize and to publicize the history, the condition and the claims of their communities and groups by means of the art-literature.

Keywords: Indian literature; Literature of Minorities; Community-Individual; Activism; Militancy.

Não vejo como dar um caráter educativo aos fatos e eventos que deram sentido à nossa luta, numa década cheia de protagonismos como foi aquela de 1970 e 1980, a não ser que possam ter interesse por conhecer essa fase da nossa história brasileira. Pois não se trata de história indígena, mas da sociedade brasileira se libertando da ditadura, com todas as consequências que isso representou para a sociedade como um todo: democracia, direitos humanos, justiça social, participação cidadã. Tudo isso foi criação desse período. Saímos da ditadura bruta, sem direito nenhum, para a invenção da democracia, com ampla participação dos povos todos: índios, negros, amarelos, azuis, cor-de-rosa, vermelhos... isso é uma coisa estonteante... Como passar isso para quem não viveu? Talvez fazendo literatura... (KRENAK apud MUNDURUKU, 2012, p. 83).

\section{Considerações iniciais}

esse texto, tendo por base uma visão genérico-sintética da literatura indígena brasileira produzida no Brasil nas últimas décadas, defenderemos duas ideias centrais que, em nossa compreensão, definem o sentido e perpassam a constituição e a vinculação público-política dessa mesma literatura indígena brasileira como ativismo e militância que parte da tradição ancestral-comunitária e se afirma como crítica do presente, sob a forma de um eu-nós lírico que é político-politizante, carnal e vinculado, diretamente ligado ao e dependente do Movimento Indígena brasileiro. A primeira delas consiste em que, situando-se no horizonte epistemológicopolítico mais geral constituído pela literatura de minorias, a literatura indígena brasileira assume esse sentido diretamente político-politizante, carnal e vinculado acima comentado, em que há uma imbricação profunda, indissociável e pungente (por isso o sentido político-politizante, carnal e vinculado) entre indivíduo e comunidade-grupo, gerando um eu-nós líricopolítico que, enquanto minoria, publiciza, promove, desvela e denuncia, no próprio exercício de expressão estético-literária, a alteridade, a diferença 
que está na base de sua condição (construída politicamente) como minoria, juntamente com toda a marginalização, negação, exclusão e violência vividas e sofridas enquanto tal.

A segunda delas, caudatária dessa primeira, está em que, por causa disso, a voz-práxis estético-literária indígena constitui-se como ativismo e militância enquanto minoria marginalizada, rompendo com o silenciamento a ela imposto e assumindo-se exatamente como voz-práxis público-política, que, de modo correlato, afirma e promove suas tradições comunitárias e se posiciona enquanto crítica do presente, o que significa que a construção metodológico-programática e o embasamento epistemológicopolítico dessa mesma literatura indígena são definidos por essa pertença e essa condição como minoria, por esse ativismo e essa militância, por essa ligação umbilical com o Movimento Indígena brasileiro e em favor da causa indígena. Nesse sentido, é essa constituição política-politizante, carnal e vinculada, que vai da autoexpressão como e da afirmação da tradição ancestral-comunitária à crítica do presente, a tradição comunitária como crítica do presente, em termos de ativismo e militância do eu-nós líricopolítico, que propomos, nesse texto, enquanto estilística e modo de análise e de recepção da voz-práxis estético-literária indígena, seja na postura de seus intelectuais, seja no resultado (e em termos de publicização) de suas obras, seja, por fim, em sua ligação ao Movimento Indígena, conforme comentado logo acima.

Gostaríamos de esclarecer alguns termos fundamentais na constituição deste trabalho. O primeiro e mais fundamental deles consiste nos conceitos de voz-práxis e de obra-práxis. Queremos, com eles, significar que a autoexpressão das minorias por si mesmas e desde si mesmas, diretamente, sem mediações institucionalistas, cientificistas e tecnicistas, via produção estético-literária, lhes permite a constituição de uma perspectiva crítica, reflexiva e emancipatória que apresenta um triplo e imbricado movimento: possibilita a autoexpressão a partir da própria singularidade que esteve na base dos processos de genocídio, de etnocídio, de silenciamento e de invisibilização aos quais as minorias foram e são submetidas; leva a um movimento catártico de reconstrução da própria história, da própria condição e, com isso, à autoafirmação como minoria, como diferençaalteridade; e, como consequência, consolida uma perspectiva de ativismo, de militância e de engajamento como o caminho para a crítica social, a resistência cultural e a luta política, em que a minoria vai à esfera públicopolítica por meio da arte-literatura e toma partido em favor de sua situação. É uma voz que se constitui como práxis, uma obra que se faz práxis, e uma práxis que se faz voz e obra: na reflexividade exigida, fomentada e desenvolvida pela escrita desde si mesmo e por si mesmo gera-se essa dinâmica catártica, crítica e transformadora que o relato autobiográfico, testemunhal e mnemônico das minorias sustenta e dinamiza.

Nesse sentido, e esse seria nosso segundo conceito a ser esclarecido aqui, argumentamos que a literatura de minorias de um modo geral e a literatura indígena em particular são constituídas e constituem um eu-nós lírico-político ativista, militante e engajado que se utiliza de uma voz-práxis estético-literária carnal, vinculada e política-politizante como forma de publicização, querendo com isso significar que o/a autor/a de minorias fala desde sua condição, a partir dela, sem qualquer desvinculação, despolitização, formalismo e tecnicismo acerca dela. Não há mediação, aqui, mas fala-práxis direta e pungente, dita em primeira pessoa, que imbrica arte, verdade e política, a arte como politização, a verdade como ativismo, militância e engajamento. Por fim, queremos enfatizar que trabalhamos, no texto, com Ailton Krenak, Daniel Munduruku, Davi Kopenawa e Eliane Potiguara como exemplo de escritores/as indígenas; mas é importante salientar que o rol dos/as escritores/as indígenas brasileiros/as, na atualidade, é muito mais amplo e diversificado, contando com mais de trinta 
autores/as, tais como, ainda, Márcia Kambeba, Tiago Hakyi, Olívio Jekupé, Kaká Werá, Yaguarê Yamã, Ely Macuxi, Cristino Wapixana, Graça Graúna etc.

\section{Literatura indígena brasileira como literatura de minorias: quatro questões propedêuticas}

A literatura indígena brasileira, tal como ela é desenvolvida na atualidade em seus/suas múltiplos/as intelectuais-escritores/as, possui quatro especificidades basilares que a constituem e a dinamizam de modo fundamental, a saber: ela faz parte do horizonte mais geral representado pela literatura de minorias, assumindo-se, nesse sentido, como política-politizante, carnal e vinculada, uma vez que as minorias são uma construção política e sua expressão pública enquanto minorias é, de antemão e pungentemente, uma práxis político-normativa; ela é marcada pela correlação e pela mútua dependência entre comunidade e indivíduo, de modo que este fala em nome daquela e aquela é o substrato da voz-práxis deste; ela parte da retomada e da reafirmação da tradição ancestral-comunitária e chega à crítica do presente, o que significa que essa mesma tradição ancestral-comunitária é estilizada-utilizada exatamente como crítica do presente, como publicização e promoção culturais e como denúncia da violência vivida e sofrida enquanto minoria; e ela é constituída por uma voz-práxis ativista e militante que coloca em xeque, que recusa uma perspectiva meramente individualista, diletante e voyeurista própria a muitas expressões estético-literárias modernas, marcadas por uma subjetividade absoluta, apolítica e despolitizada, independente e sobreposta ao contexto de que emerge, apontando, por conseguinte, para uma postura de crítica social, resistência cultural e luta política enquanto grupo étnicocultural, enquanto minoria político-cultural, perspectiva política-politizante e cultural-comunitária como seu núcleo epistemológico-normativo e metodológico-programático constitutivos mais contundentes. Nesse sentido, levando-se em conta essas quatro especificidades basilares, podemos definir a voz-práxis estético-literária indígena como ativismo e militância que se liga direta e pungentemente ao Movimento Indígena brasileiro enquanto afirmação, resistência e luta dos povos indígenas desde sua singularidade e a partir de sua condição de vítimas da modernização periférica e excludente (calcada em uma perspectiva antropológico-cultural eurocêntrica) própria ainda hoje à constituição e à evolução da sociedade brasileira, uma vozpráxis, portanto, que se constitui e se dinamiza enquanto publicização estética, epistemológica, política e cultural dos povos indígenas desde si mesmos e por si mesmos, sem mediações institucionalistas e rompendo com cientificismos assépticos. Reflitamos sobre esses pontos.

Com efeito, quando lemos e analisamos a produção estético-literária das minorias de um modo geral e dos intelectuais-escritores indígenas em particular, nos impressiona exatamente esse sentido político-politizante, carnal e vinculado da voz-práxis por eles emanada, da obra-práxis por eles produzida. As minorias, nesse sentido, são $a b$ initio uma construção fundamentalmente política, moral, cultural, e não um produto essencialista e naturalizado, de cunho a-histórico, apolítico e despolitizado. Elas não surgiram no nada, mas sim a partir da intersecção e do conflito entre grupos socioculturais e paradigmas epistemológico-políticos antagônicos (ou que se julgavam antagônicos), resultando em disputas que assumiram tanto uma dinâmica normativa que legitimava a contraposição e a superioridadeinferioridade dos e entre os grupos socioculturais quanto, em muitos casos, uma perspectiva colonialista e genocida de uns para com os outros, alcançada por meio de longos e contínuos processos de silenciamento político-normativo, de formatação cultural e de destruição material (cf. SPIVAK, 2010, p. 77-129; MIGNOLO, 2007, p. 117-168; CHAKRABARTY, 2002, p.138-148; BHABHA, 1998, p.22-59). Isso significa, evidentemente, que 
forças e processos políticos e culturais, localizados no espaço e no tempo, construíram hegemonicamente essas mesmas minorias que, repetimos, não são um dado a priori, natural, mas sujeitos, relações e valores políticos.

Ora, enquanto construção social, cultural, política e epistêmica, a vozpráxis das minorias, uma vez publicizada, é política em um duplo sentido, a saber: primeiro, porque representa a expressão público-política de uma minoria por si mesma e desde si mesma, na medida em que sua voz-práxis assume normativamente a singularidade que embasa e perpassa o grupo em questão, bem como explicita publicamente essa especificidade e, em consequência, enquadra padrões supostamente essencialistas, naturalizados e normalizados-normalizadores dos grupos sócio-culturais hegemônicos, politizando a estes (cf.: BUTLER, 2003, p.185-202; FANON, 1968, p.197208; DUSSEL, 1993, p. 159-180; MBEMBE, 2001, p. 102-141; DALCASTAGNÈ, 2012, p. 49-74). No primeiro caso, as minorias na esfera pública são políticas e politizantes porque se expressam de modo alternativo e contraposto à ordem naturalizada, a-histórica, apolítica e despolitizada fundada e sustentada pela normalização, pela unidimensionalização e pela totalização da perspectiva axiológica e do status quo dos grupos hegemônicos - o que significa que as diferenças, as alteridades, uma vez assumindo-se e constituindo-se em termos de esfera pública, são irremediavelmente políticas, como condição de sua expressão, de sua ação, de sua afirmação enquanto minorias, enquanto diferenças-alteridades. No segundo caso, as minorias, que somente podem sobreviver e resistir enquanto esfera pública, isto é, enquanto sujeitos políticos que publicizam e enfrentam publicamente sua causa, que questionam os sujeitos, os padrões, as relações e os valores normalizados, apolíticos, despolitizados e massificadores instaurados ao longo do tempo por parte dos grupos socioculturais hegemônicos.

É por isso que dissemos, acima, que as minorias são irremediavelmente políticas (nesse duplo sentido, como postura-práxis e como construção, como afirmação e ação públicas e como crítica social e resistência cultural no que diz respeito aos sujeitos, valores e relações normalizadores), uma vez que sua voz-práxis somente pode afirmar-se e resistir publicamente, o que também significa, uma vez mais, o enfrentamento dos sujeitos, dos processos, das relações, das instituições e dos valores a-históricos, apolíticos, despolitizados e massificadores que sustentam a naturalização e, com isso, o sentido a-histórico e a despolitização dessas mesmas diferenças. Nesse diapasão, é imperioso que as minorias saiam da esfera privada de vida e assumam-se como sujeitos, práticas, relações e valores público-políticos, rompendo com a sua subsunção ao privatismo, às esferas do lar e do quarto basicamente (ou, no caso dos povos indígenas, do mato - essa imagem que lhes foi imposta política, epistemológica e culturalmente pela colonização e, depois, por nossa modernização conservadora, uma imagem congelada no passado e que legitima exatamente essa ideia dos povos indígenas como sujeitos do passado, não do presente), levada a efeito por meio de processos de colonização, de alienação e de silenciamento dinamizados por grupos socioculturais hegemônicos (cf.: FANON, 1968, p.87-120; QUIJANO, 1992, p.11-20; CHAKRABARTY, 2002, p. 20-37).

Enquanto estiverem reduzidas a essa esfera privada, não-pública, as minorias, as alteridades-diferenças são anuladas em sua singularidade, reduzidas a um grupo e a um sujeito apolíticos e despolitizados - o silenciamento e a anulação sendo possibilitados pela subsunção dessas minorias à esfera de vida privada, como esfera de vida privada. Aqui, somente a publicização e a politização de sua singularidade e de sua condição, a publicização e a politização de si e dos sujeitos, das relações e dos valores socialmente hegemônicos têm condições, se não de frear totalmente processos de exclusão, de marginalização e de negação contra essas mesmas minorias, pelo menos de enquadrá-los e de contrapô-los, o que apenas pode ser feito em termos público-políticos, por meio dessa politização direta e 
radical que estamos chamando enquanto condição e atitude dessas mesmas minorias.

É nesse sentido, aliás, que as produções estético-literárias das minorias e por essas mesmas minorias representam, hoje, um dos grandes baluartes da democracia, da crítica social, da resistência cultural e da luta política de grupos e sujeitos tradicionalmente marginalizados, excluídos e silenciados. Pensemos, aqui, no crescimento da literatura de minorias, do/a negra, do/a indígena, do/a homossexual, da mulher, etc., enquanto exemplos dessas minorias (de todo modo, estamos enquadrando essas alteridades na categoria das minorias, significando, por esse termo, grupos socioculturais e até em termos de gênero, de sexualidade e de religião tradicionalmente anulados pelos padrões normalizadores, essencialistas e naturalizados próprios à correlação de eurocentrismo, brancura, Cristianismo, machismo e heterossexualismo) (cf. MUNDURUKU, 2004, p.14-16; DALCASTAGNÈ, 2012, p. 07-14; BUTLER, 2003, p. 49-60).

Nessas produções estético-literárias das minorias, nós percebemos uma perspectiva política-politizante, carnal e vinculada que assume o duplo sentido do conceito de minorias acima desenvolvido: de um lado, trata-se de afirmar-se e expressar-se a partir de sua singularidade antropológica e dos valores, das práticas e dos símbolos desde ela formados, sem medo ou vergonha; de outro, mas de modo mutuamente dependente, trata-se de assumir uma voz-práxis de alcance público, que se consolida e atua na e como esfera pública, desvelando, denunciando e criticando os sujeitos, os processos e os valores que geram, sustentam e fomentam a marginalização, a negação e a violência contra essas mesmas diferenças. Em consequência, as produções estético-literárias das minorias apresentam um eu-nós líricopolítico carnal, vinculado e politizante, isto é, comprometido com um grupo e sua causa, afirmador do grupo e de sua causa, uma voz-práxis que fala de modo veritativo, rompendo pura e simplesmente com uma ficcionalidade sem compromisso político e sem ligação com a crítica e a verdade para assumir-se como relato autobiográfico da singularidade antropológica, da condição e da pertença como alteridade-diferença, como minoria. Veja-se, nesse sentido, o relato autobiográfico de Daniel Munduruku:

O mestrado, que iniciei em 1992, não consegui concluir. Minhas idas constantes à aldeia de meus antepassados me envolveram mais do que deveriam e as leituras e disciplinas foram sendo deixadas para trás. Mais ainda os textos que deveria escrever para compor a dissertação à qual me propusera.

A teoria não estava me interessando mais que a prática e o comprometimento com os destinos de meu povo. Preferia ficar lá procurando junto com a comunidade maneiras de nos livrar dos garimpeiros que invadiam nosso território tradicional atrás de ouro. Faziam isso à revelia da lei nacional que nos protegia. Queriam arrancar nosso ouro, mas não ligavam se para isso estavam destruindo nosso habitat natural e ancestral. Não respeitavam a terra ou os rios; nossos territórios simbólicos (tinha aprendido isso na antropologia); nossos sítios e cemitérios; nossos espaços sagrados que serviam de referência para a construção de nossa memória ancestral. Como poderia presenciar isso sem me compadecer? Como poderia ver a violência acontecendo e tomar o partido da ciência que me dizia que eu deveria ser um observador imparcial e objetivo? Eu não conseguia. Havia uma dor aguda apertando meu peito e uma dúvida que me prendia a respiração (MUNDURUKU, 2016, p.165-166).

Aqui está, de fato, o ponto epistemológico-político e metodológicoprogramático fundamentais da arte e da literatura de minorias: elas não são apenas e nem fundamentalmente ficções, criações ex nihilo, destituídas de uma causa e de um compromisso políticos, normativos e epistêmicos, mas fatos concretos, constructos fundados em e dependentes de experiências materiais de vida e de violação da própria identidade, que se dá nessa intersecção de pertença e história comunitárias, culturais e grupais com a perspectiva pessoal, subjetiva do/a escritor/a, do/a intelectual. São produções estético-literárias dependentes de e fundadas em uma voz-práxis que se pretende verdadeira, justificada moral, normativa e politicamente em 
termos de criticismo social, resistência cultural e práxis política, por causa da condição de minoria, sob a forma de uma voz-práxis política e politizante, carnal e vinculada da e pela minoria ${ }^{1}$.

No mesmo sentido, como se pode perceber na memória autobiográfica de Daniel Munduruku, acima citada, a objetividade epistemológico-moral e a consequente justificação político-normativa são dadas exatamente pelo ativismo e pela militância, isto é, pelo fato de que a minoria e o/a intelectual de minorias agem na práxis e como práxis, sem mediações, imbricando, por causa de sua condição de minoria e com base na intersecção de história e condição comunitárias e grupais e destino individual, teoria e prática sob a forma do ativismo e da militância que comentamos acima. Nesse sentido, para o/a intelectual, para o/a escritor/a de minorias, sua alteridadediferença, na condição de vítima excluída, marginalizada e violentada, não apenas não pode ser abandonada e nem dela e sobre ela se pode perder a sensibilidade relativamente à situação do grupo, da comunidade, senão que também não há como livrar-se da pertença, do compromisso e da visibilidade que essa mesma pertença lhe confere em sua manifestação público-política. Ele/a é, sempre e permanentemente, intelectual, escritor/a de minorias, diferença-alteridade radical e, assim, sua voz-práxis é direta e pungentemente ativismo e militância.

1 Essa é a posição de Regina Dalcastagnè relativamente à literatura de minorias, que corroboramos: [...] Quando entendemos a literatura como uma forma de representação, espaço onde interesses e perspectivas sociais interagem e se entrechocam, não podemos deixar de indagar quem é, afinal, esse outro, que posição lhe é reservada na sociedade e o que seu silêncio esconde. Por isso, cada vez mais, os estudos literários (e o próprio fazer literário) se preocupam com os problemas ligados ao acesso à $v o z$ e à representação dos múltiplos grupos sociais. Ou seja, eles se tornam mais conscientes das dificuldades associadas ao lugar da fala: quem fala e em nome de quem. Ao mesmo tempo, discutem-se as questões correlatas, embora não idênticas, da legitimidade e da autoridade (palavra que, não por acaso, possui a mesma raiz de autoria) na representação literária. Tudo isso se traduz no crescente acaso, possui a mesma raiz de autoria) na representação literária. Tudo isso se traduz no crescente debate sobre o espaço, na literatura brasileira e em outras, dos grupos marginalizados - entendidos, m sentido amplo, como todos aqueles que vivenciam uma identidade coletiva, que recebe valoração negativa da cultura dominante -, que sejam definidos por sexo, etnia, cor, orientação sexual, posição nas relaçães de produção, condição física ou outro critério (DALCASTAGNE, 2012, p.17; os destaques
são da autora).
Trata-se, por conseguinte, de uma voz-práxis estético-literária que já não pode ser enquadrada como não-científica, como mera opinião fantasiosa, como delírio do/a escritor/a, como sua invenção imaginativa pura e simplesmente, do mesmo modo como já não se pode atribuir o critério de verdadeveracidade apenas ao juízo científico, em sua neutralidade, imparcialidade, impessoalidade e formalidade, tal como pressuposto no modelo canônico retirado das ciências da natureza em sua noção de objetividade como neutralidade, imparcialidade, impessoalidade e formalismo axiológico-metodológicos (cf. SPIVAK, 2010, p.19-47; HONNETH, 2007, p.61-65; HABERMAS, 2002, p.17-53). De fato, conforme pensamos, a voz-práxis estético-literária das minorias, sob a forma de ativismo e de militância, rompe com a cisão entre ciência e arte, juízo científico e juízo estético, uma vez que também se coloca como objetiva, verdadeira, justificada, porque relato testemunhal, mnemônico e experiencial da minoria por si mesma e desde si mesma, diretamente, sem mediações institucionalistas, cientificistas e tecnicistas; ela rompe e, mais ainda, amalgama uma e outra (isto é, ciência e arte), no sentido de que também o juízo estético-literário é verdadeiro e, por isso, tem condições de assumir-se diretamente como crítica social e práxis político-normativa.

Ora, o juízo estético-literário produzido em termos de voz-práxis das minorias é verdadeiro porque ele é construído a partir dessa correlação entre singularidade antropológica e experiência de marginalizaçãoexclusão-negação que somente a vítima pode explicitar, biografar e, portanto, publicizar em toda a sua pungência, em todo o seu simbolismo e em toda a sua materialidade. A vítima jamais pode ser substituída ou sequer representada em toda a sua dor desde fora, pelo pesquisador asséptico e em termos da impessoalidade, da neutralidade, da imparcialidade e do formalismo acima comentados (cf. DANNER; DORRICO PERES, 2017, p. 129156). Aqui, em termos de voz-práxis estético-literária como ativismo e militância diretos e pungentes, por conseguinte, as vítimas falam objetiva e 
justificadamente sobre sua condição e sobre a questão da opressão de um modo mais geral, sendo insubstituíveis e irrepresentáveis e, em verdade, tornando-se a condição fundante da crítica social, da resistência cultural e da transformação política, um papel epistemológico-político e uma condição normativa que não possuem substitutivo (e sequer o cientificismo poderia ser essa alternativa à própria voz-práxis das minorias por si mesmas e desde si mesmas). Note-se, assim, que há um amálgama entre arteliteratura, cientificidade (como objetividade e justificação intersubjetiva) e crítica por causa da condição de vítima, por causa da singularidade das diferenças-alteridades que, através da militância e do ativismo, enquadram, desnaturalizam, historicizam e, com isso, politizam radicalmente os grupos socioculturais, a esfera pública, as práticas, os valores e as relações cotidianas naturalizados, retirando-lhes o sentido a-histórico, apolítico e totalizante, afirmando-os como construções humanas no espaço e no tempo históricos, dependentes de sujeitos sociopolíticos e de suas relações recíprocas (elas mesmas localizadas no espaço e no tempo).

É claro, de todo modo, que a verdade e a justificação normativas, no caso das minorias, já não são mais fundadas e nem dinamizadas por uma subjetividade asséptica e por um procedimento altamente institucionalista calcados em e dependentes de imparcialidade, neutralidade, impessoalidade e formalidade metodológico-axiológicas. As diferenças-alteridades, as minorias, em sua voz-práxis, possuem um apelo veritativo e uma justificação normativa que se fundam exatamente na sua condição política como minorias - singularidade antropológica e negação-exclusão-marginalização social-cultural e epistemológico-política - e que dependem do ativismo e da militância na esfera pública e como esfera pública (e da intensidade com que o ativismo e a militância das minorias por si mesmas e desde si mesmas se processam na e como esfera pública) para a viabilização efetiva e consistente da crítica social, da resistência cultural e da transformação política.
É nesse sentido que dissemos, acima, que (a) a voz-práxis das minorias, das diferenças-alteridades é sempre política-politizante, carnal e vinculada, constituída e dinamizada sob a forma de ativismo e de militância na esfera pública e como publicidade radical da condição de minorias; bem como que (b) essa mesma voz-práxis das minorias por si mesmas e desde si mesmas assume uma pretensão de verdade e uma justificação normativa que não podem ser enquadradas e nem subsumidas pelo paradigma científico e em termos da correlação de institucionalismo e cientificismo, o que significa que, no caso da voz-práxis das minorias por si mesmas e desde si mesmas, a verdade e a justificação normativa não são e nem podem ser fundadas na imparcialidade, na neutralidade, na impessoalidade e no formalismo metodológico-axiológicos, centralizados, monopolizados e dinamizados por uma comunidade de pesquisa altamente esotérica e institucionalista, que serve de árbitro-juiz, guia e ponte entre o cotidiano e as instituições, que enquadra e orienta a esfera público-política desde essa correlação de institucionalismo e de cientificismo acima comentadas. Ora, no cientificismo, a verdade e a justificação normativa dependem exatamente da palavra final do analista e somente podem ser construídas por meio de uma metodologia e de uma axiologia que não apenas separam teoria e prática, senão que também subsumem a prática à institucionalização e à comunidade de pesquisa, constituídas de modo sobreposto e autorreferencial e, por isso, em seu entender, asséptico e autônomo relativamente aos sujeitos, às práticas, às vinculações e aos valores cotidianos ${ }^{2}$.

2 É desse modo, como forma de corroboração, que Almeida \& Queiroz, nos falando sobre o desenvolvimento da literatura indígena, afirmam que "[...] os povos indígenas iniciam uma retomada do diálogo com a Europa. Atravès da criação e da circulação de novas formas, eles entram no circuito literario, e se
envolvem na problemática da escrita e da publicação. Diversos entre si e da chamada literatura ocidental moderna, os textos indígenas despolarizam, até quase a dissolução, os parâmetros canônicos, deixando a descoberto a teoria literária baseada na tradição escrita" (ALMEIDA; QUEIROZ, 2004, p. 198) 
Ora, a imparcialidade, a neutralidade, a impessoalidade e o formalismo metodológico-axiológicos são a expressão e a forma mais clara desse cientificismo e desse institucionalismo forte no que se refere tanto à construção do conhecimento verdadeiro quanto à legitimação políticonormativa da práxis dali adveniente, dali possibilitada: eles exigem dos sujeitos epistemológico-políticos uma perspectiva apolítica-despolitizada em que o juízo cognitivo somente pode alcançar objetividade e, portanto, validade intersubjetiva a partir do distanciamento e da separação entre analista e analisado, de modo que, se a construção do juízo científico é feita por um analista asséptico, sua posterior aplicação é dinamizada e realizada por um tecnocrata que, a partir de uma postura altamente institucionalista e lógico-técnica, está sobreposto e é independente em relação aos sujeitos epistemológico-políticos cotidianos, suas lutas, relações, práticas e valores (DANNER; BAVARESCO; DANNER, 2015, p.15-48). Como estamos argumentando, essa perspectiva epistemológico-política e metodológicoprogramática altamente cientificistas, institucionalistas, assépticas e apolíticas não podem ser aplicadas à voz-práxis das minorias e, em verdade, essa mesma voz-práxis das minorias, em termos estético-literários, subverte e transforma a correlação de verdade-objetividade, cientificismo e institucionalismo (em termos de impessoalidade, neutralidade, imparcialidade e formalismo), instituindo o ativismo e a militância como o caminho a partir do qual a verdade e a justificação normativa são construídas e aplicadas, são fundadas e utilizadas no dia a dia, uma vez que, conforme estamos argumentando, as minorias, as diferenças-alteridades, dada sua politicidade radical, desnaturalizam, historicizam e politizam o status quo, as instituições, os valores, as práticas e os grupos socioculturais.

Nesse aspecto, acreditamos que somente as diferenças-alteridades podem viabilizar em toda a sua potência e efetividade a crítica social, a resistência cultural e a transformação política, uma vez que elas quebram com a normalização, com a massificação e a totalização, uma vez que elas, na sua própria condição de minoria e superando o privatismo, o confinamento, a subsunção e o silenciamento próprios à vida privada e adentrando e consolidando-se na esfera pública, politizam radicalmente tudo e todos, expondo a historicidade-politicidade dos sujeitos, das práticas, dos valores e das instituições socialmente vinculantes - além de, evidentemente, superarem o cientificismo neutro, impessoal, imparcial, asséptico e formal. Aqui, como dissemos acima, as minorias, as alteridadesdiferenças são direta e pungentemente políticas e politizantes, carnais e vinculadas, e é desde essa condição que a obra-práxis por elas produzida se transforma em ativismo e militância, em autoexpressão e autoafirmação e, a partir daqui, conduzem à crítica social, à resistência cultural e à luta política, definindo e legitimando a verdade e a correção normativa exatamente como voz-práxis construída e dinamizada em termos da correlação de primeira pessoa do singular e terceira pessoa do plural, o eu-nós lírico-político que publiciza tanto sua singularidade antropológicocomunitária quanto sua condição de vítima de sujeitos, práticas, valores e instituições normalizadores, massificadores e totalizantes. Verdade e correção normativa, portanto, passam a ser construídas e justificadas por meio do ativismo e da militância, por meio da politização e da publicização de um eu-nós lírico-político que, saindo do privatismo e recusando o silenciamento, publiciza-se e, com isso, politiza os sujeitos, as estruturas, as instituições, os valores e as práticas naturalizados, normalizadosnormalizadores, recusando seu sentido essencialista, naturalizado e a-histórico, apolítico e despolitizado ${ }^{3}$.

3 Como diz Eliane Potiguara relativamente aos povos indígenas: “O indígena brasileiro não pode mais ser idolatrado na sua cultura e arte, nas suas fotografias, nas suas artes cinematográficas, nas suas expressões literárias e orais e ser literalmente ignorado na sua condição física, humana, social e política" (POTIGUARA, 2004, p. 95). 
Aqui podemos situar outro ponto fundamental das produções estéticoliterárias, da voz-práxis estético-literária das minorias de um modo geral e da literatura indígena em particular, que é exatamente a profunda correlação entre comunidade-grupo e indivíduo, tradição comunitárioancestral e indivíduo, destino e condição coletivos e história pessoal, que dá origem ao eu-nós lírico-político acima comentado, isto é, à profunda e inextricável conexão entre comunidade-grupo e indivíduo enquanto o núcleo ontogenético e epistemológico-político dos/as intelectuais, dos/as escritores/as de minorias, de modo que sua obra-práxis transita do indivíduo à comunidade e da comunidade ao indivíduo. Essa é uma característica que, como estamos afirmando no texto, é definidora de toda a produção estéticoliterária das e pelas minorias, a saber, a ligação umbilical, a pertença antropológica e a dependência epistemológico-política à comunidade, ao grupo, à tradição comunitária-grupal-ancestral, no duplo sentido do termo: como minoria, o/a intelectual bebe na singularidade antropológicoontológica, sociocultural e epistemológico-política da comunidade ou do grupo de que faz parte; como minoria, ele, ao publicizar sua voz-práxis, direta e pungentemente exprime-se como alteridade-diferença, como pertencente a uma dada minoria negada, marginalizada, violentada, não conseguindo de nenhum modo - e certamente nem querendo - abandonar essa sua condição originária e política-politizante, carnal e vinculada.

Ele é, sempre e permanentemente, minoria, diferença-alteridade. Ora, essa correlação e mútua dependência entre comunidade-grupo e indivíduo, embasada na e afirmadora da condição de minoria, leva exatamente a uma voz-práxis público-política que traz para o centro do debate político, cultural e institucional a própria condição das minorias em sua diferença radical e em sua situação de marginalização, silenciamento e violência. Nesse sentido, nas produções estético-literárias das e pelas minorias de um modo geral e dos/as e pelos/as indígenas em particular, nós percebemos exatamente a tematização da própria condição antropológico-comunitária e dessa situação de marginalização, de exclusão e de violência vividas e sofridas, que, ao retirar o silenciamento acerca delas, também enquadra criticamente o horizonte social, cultural, político, epistemológico e institucional que sustenta e reproduz a exclusão e a despolitização, que leva à privatização da causa das minorias, da causa indígena em nosso caso. Aqui está, conforme acreditamos, uma das contribuições fundamentais da arte-literatura de minorias de um modo geral e da arte-literatura indígena em particular, que consiste exatamente em trazer para o núcleo do debate epistemológicopolítico e sob a forma de esfera pública, de publicidade, a condição dessas mesmas minorias, a causa indígena, o Movimento Indígena, de modo que o/a intelectual de minorias, o/a escritor/a de minorias, que já não se dissocia do grupo ou da comunidade de que faz parte, que já não dissocia seu posicionamento e sua expressão relativamente ao grupo ou à comunidade de que faz parte, estrutura, assume, utiliza e dinamiza sua voz-práxis exatamente como ativismo e militância diretos e pungentes. Na sua (do/a autor/a, do/ escritor/a de minorias) voz-práxis e em suas consequentes produções e manifestos público-políticos, portanto, as diferenças/ alteridades são alçadas ao patamar de sujeito, valor, prática e condição epistemológico-políticos fundantes da crítica social, da resistência cultural e da transformação política, tornando-se, a partir da expressão de sua singularidade antropológico-cultural e de sua condição de marginalização enquanto minorias, base da politização e da desconstrução de sujeitos, relações, práticas e valores normalizados e normalizadores, totalizantes e massificadores, de modo a colocar-se em xeque o essencialismo, a naturalização, a a-historicidade e, em consequência, a despolitização da sociedade, de seus sujeitos, de suas relações, de suas práticas e de seus valores. Por meio das diferenças e desde sua singularidade/condição, essa mesma sociedade e tudo o que ela contém tornam-se politizados, 
historicizados, democratizados, posto que desnaturalizados (cf. SPIVAK, 2010, p.19-126; FANON, 1968, p.23-74; MBEMBE, 2014, p.278-286; CHAKRABARTY, 2000, p. 97-116).

Desse modo, a voz-práxis estético-literária das minorias, uma vez que é política-politizante, carnal e vinculada, isto é, uma vez que constitui um eu-nós lírico-político que parte da correlação entre comunidade-grupo e indivíduo, condição coletiva e história individual, possui um movimento constitutivo e uma atuação público-política marcados por uma dinâmica epistemológico-política muito específica, isto é, por um movimento que vai da tradição ancestral-cultural e da condição comunitário-grupal à crítica do presente, a singularidade e a situação das minorias como crítica do presente. Na literatura de minorias, esse movimento politizante e essa dinâmica constitutiva que vão da comunidade-grupo à e como crítica do presente potencializam o posicionamento público-político dessas mesmas minorias e de seus/suas intelectuais na esfera pública. É por causa dessa singularidade antropológica e dessa situação social, cultural, política, econômica e até religiosa das minorias que seus/suas intelectuais têm condições e legitimidade para falar e agir em nome da democracia, exigindo democracia porque se explicitando como vítimas de um processo societal, cultural e institucional produtor e legitimador da marginalização de grupos socioculturais específicos. Suas experiências antropológicas e sua condição de marginalização, sua condição/situação dupla enquanto minorias (singularidade antropológico-comunitária e vítimas), uma vez publicizadas, uma vez rompendo com o silenciamento e a privatização a elas impostos pelos grupos hegemônicos, permite a politização radical da situação, dos sujeitos, das práticas e dos valores que geram, legitimam e reproduzem a marginalização e a exclusão, bem como o enquadramento da vida cotidiana, em suas potencialidades e em seus problemas, a partir de outras perspectivas axiológicas, trazendo-nos, no primeiro caso, o esclarecimento que nenhuma visão de mundo totalizante e unidimensional pode dar (esclarecimento que somente as diferenças/alteridades podem propiciar, detonar) e alternativas vitais, institucionais e valorativas acerca de nossos problemas cotidianos.

Note-se que a atuação público-política dos/as intelectuais, dos/as escritores/as ligados às minorias enriquece a democracia e a politiza por causa exatamente do duplo sentido do termo minoria, diferença/ alteridade, isto é, por causa dos valores, das práticas e dos sujeitos epistemológico-políticos específicos à singularidade antropológica do grupo ou da comunidade em questão, e por causa das experiências de exclusão, marginalização, exclusão e violência que essas minorias têm e vivem cotidianamente, de modo que em um e em outro caso sua voz-práxis, tornando-se ativa e militante publicamente, tem condições de politizar, de potencializar a crítica e o aperfeiçoamento de sujeitos, relações/situações, práticas e valores cotidianos que são problemáticos, que necessitam de revisão crítica, uma postura reflexiva e emancipatória que somente acontece no encontro e na interação com as diferenças/alteridades, com as minorias não apenas como sujeitos, condições, práticas e valores insubstituíveis e irrepresentáveis, mas também como a base a partir do qual a massificação, a totalização e a unidimensionalização se fazem perceptíveis e podem ser enquadradas - as diferenças/alteridades como os sujeitos, a práxis, a condição e os valores a partir dos quais a sociedade é desnaturalizada, historicizada e politizada, como dissemos ao longo do texto (cf. HONNETH, 2003, p. 125-156).

Com isso, a voz-práxis estético-literária das minorias por si mesmas e desde si mesmas constitui-se direta e pungentemente sob a forma de ativismo e de militância como seu núcleo, sentido e direcionamento mais fundamentais, o que significa a politização radical da expressão estéticoliterária, que passa a ligar-se inextricavelmente e promover a causa do grupo de que faz parte o/a escritor, o/a intelectual em questão - dadas a 
umbilical ligação e a profunda dependência que ele/ela possui em relação ao grupo ou à comunidade de que faz parte, dada a condição originária dele/dela como minoria, como diferença/alteridade (em termos de singularidade antropológico-cultural e de estigma político). No caso das minorias, trata-se de uma voz-práxis política-politizante, carnal e vinculada, em que a expressão estético-literária publicizada é a expressão da singularidade $e$ da condição da própria minoria à qual pertence o/a escritor/a, tornando-se, em verdade, a voz-práxis da minoria por si mesma e desde si mesma. É nesse sentido, portanto, que a arte-literatura de minorias constitui-se e assume-se diretamente como ativismo e militância político-politizantes, carnais e vinculados, posto que não se pode abandonar a condição de diferença/alteridade, de minoria enquanto singularidade antropológicocultural e como vítima político-normativa de sujeitos, de processos e de valores políticos, o que implica em que, desde o início, a condição de minoria imbrica e explicita/publiciza a pertença ao grupo em questão, explicita/publiciza a condição e a situação atuais desse grupo ou dessa comunidade.

O ativismo e a militância estético-literários, políticos e politizantes, carnais e vinculados, portanto, rompem com o ideal de neutralidade, imparcialidade, impessoalidade e formalidade do método e da prática científicos, que colocam a objetividade como uma condição dessa axiologia apolítica, despolitizada e sobreposta à prática de vida cotidiana dos grupos socioculturais, assim como coloca em xeque o puro e simples diletantismo e voyeurismo estético-literários de uma subjetividade absoluta, separada e independente do contexto vital, comunitário, cultural. Aqui, é exatamente o ativismo e a militância das minorias, por elas e desde elas, em nome delas, que possibilita a crítica social, a resistência cultural e a transformação política, vale dizer, a objetividade epistemológico-moral que, na linguagem da ciência, coloca-se como a base paradigmática da crítica, da reflexividade e da transformação. No caso das minorias, das diferenças/alteridades, somente o ativismo e a militância por si mesmos e desde si mesmos permitem o desvelamento da condição de marginalização, de exclusão e de violência, potencializando a crítica, a reflexividade e a transformação sociais, culturais, políticas e institucionais, condição que não pode acontecer sem a participação e a atuação público-política das minorias, que rompem com o silenciamento e a privatização a elas impostos pelos grupos social, cultural, política e institucionalmente hegemônicos. Não basta, para isso, a mediação e a representação institucional e cientificista das minorias pelo analista social; também não é suficiente uma voz-práxis estético-literária apolítica-despolitizada e voyeurista-subjetivista. 0 ativismo e a militância do eu-nós lírico-político, que imbricam a comunidade/grupo e o indivíduo, que promovem a diferença/alteridade em sua singularidade antropológica e que, a partir disso, publicizam, denunciam e combatem a condição política negativa conferida às minorias sob a forma de silenciamento, exclusão, marginalização e destruição, é que suprimem o déficit de democracia das instituições e do cientificismo, exatamente por estas mesmas minorias e seus/suas intelectuais assumirem-se como alteridade-diferença política, atuante publicamente, como sujeito, prática e valor da crítica, da reflexividade, da resistência e da transformação epistemológicas, políticas, normativas.

\section{A voz-práxis estético-literária indígena como ativismo e militância: motivos}

Definimos, acima, a voz-práxis estético-literária das minorias como ativismo e militância que tem como base a correlação comunidadegrupo-tradição e indivíduo, de modo que o/a intelectual e o/a escritor/a de minorias trazem para a esfera pública a causa, os valores e as 
práticas de sua comunidade ou de seu grupo, em uma atitude políticapolitizante, carnal e vinculada que explicita e confronta as situações de marginalização, de exclusão e de violência vividas e sofridas como minoria, como diferença-alteridade. Isso coloca a voz-práxis estético-literária em um patamar radicalmente político, como expressão de um eu-nós líricopolítico que, com sua produção, performa a dor e torna-se a voz de sua comunidade ou de seu grupo, transformando o âmbito estético-literário em crítica social, resistência cultural e luta política, o que significa a e implica na superação de uma tendência institucionalista e cientificista calcada na neutralidade, na impessoalidade, na imparcialidade e na assepsia metodológico-axiológicas. Assim, a voz-práxis estético-literária das e pelas minorias é perspectiva comprometida, engajada e vinculada direta e profundamente ao significado político das minorias, das diferenças-alteridades, somente ganhando sentido por causa dessa politização que assume relativamente à causa da comunidade ou do grupo de que faz parte.

Esse é o caso, conforme refletiremos a partir de agora, da recente produção estético-literária indígena brasileira, que passa a crescer e a se consolidar na esteira da emergência e do desenvolvimento do Movimento Indígena brasileiro a partir de meados da década de 1970, movimento esse marcado pela união dos povos indígenas e pelo fortalecimento de seu papel epistemológico, político e cultural em nossa esfera pública, com o aparecimento de importantes intelectuais e escritores/as que, com seus trabalhos, assumem exatamente a promoção e a defesa da causa indígena como o mote, o caminho e o sentido de seu trabalho e, assim, como o objetivo do próprio Movimento Indígena brasileiro. No caso das produções estético-literárias indígenas, no caso da postura público-política de seus/ suas intelectuais e escritores/as, o que vemos é exatamente uma voz-práxis que coloca a causa, os ideais e as reivindicações do Movimento Indígena como seu norte teórico-político ${ }^{4}$. Nesse sentido, é importante considerarmos uma afirmação fundamental de uma das maiores lideranças indígenas brasileiras da atualidade, Ailton Krenak (que também é escritor literário), acerca desse Movimento Indígena como uma práxis ao mesmo tempo política, cultural e estética, que se processa e se fortalece por essa imbricação de política, cultura e arte, de modo a, por um lado, trazer para o centro da esfera pública a singularidade antropológico-comunitária dos povos indígenas e sua condição de exclusão, de marginalização e de violência, bem como, por outro, interagir em torno a sínteses e trocas simbólicoculturais comuns com a cultura majoritária, em uma forma de aprendizado recíproco. Diz ele:

Se continuarmos sendo vistos como os que estão para serem descobertos e virmos também as cidades e os grandes centros e as tecnologias que são desenvolvidas somente como alguma coisa que nos ameaça e que nos exclui, o encontro continua sendo protelado. Tem um esforço comum que nós podemos fazer que é o de difundir mais essa visão de que tem importância sim a nossa história, que tem importância sim esse nosso encontro, e o que cada um desses povos traz de herança, de riqueza na sua tradição, tem importância sim. Quase não existe literatura indígena publicada no Brasil. Até parece que a única língua no Brasil é o português e aquela escrita que existe é a escrita feita pelos brancos. É muito importante garantir o lugar da diversidade, e isso significa assegurar que mesmo uma pequena tribo ou uma pequena aldeia Guarani, que está aqui, perto de vocês, no Rio de Janeiro, na serra do Mar, tenha a mesma oportunidade de ocupar esses espaços culturais, fazendo exposição da sua arte, mostrando sua criação e pensamento, mesmo que essa arte, essa criação e esse pensamento não coincidam com a ideia de obra de arte contemporânea, de obra de arte acabada, diante da sua visão estética, porque senão você vai achar bonito só o que você faz ou o que você enxerga (KRENAK, 2015, p. 166).

${ }_{4}$ Como diz Graça Graúna: "Ao escrever dou conta da ancestralidade, do caminho de volta, do meu lugar no mundo" (Escriving "Á érena). <http://ggrauna.blogspot.com/2017/09/escrevivencia-indigena.html>. Acesso em: 10 ago. 2018. 
Note-se, na passagem acima, a invectiva ao esforço de publicizar-se a causa indígena, de que os diversos povos indígenas possam dar-se a conhecer em toda a sua amplitude cultural, estética, epistemológica, política, religiosa, econômica etc. Ora, note-se, ainda, nessa passagem de Ailton Krenak, que o dar-se a conhecer essa diversidade e o dar-se a conhecer publicamente como diversidade, como alteridade-diferença, poderiam encontrar exatamente nas produções estético-literárias o lugar, o caminho e a forma dessa publicização da causa indígena, dos povos indígenas por si mesmos e desde si mesmos. Note-se, ademais, a correlação de voz-práxis estético-literária, ativismo-militância e diversidade epistemológica, política e cultural, no sentido de que, por meio dessa voz-práxis estético-literária que é por excelência política-politizante, carnal e vinculada, a pluralidade é expressa e se expressa sem reducionismos, sem generalizações e sem massificações, inclusive prescindindo de mediações institucionalistas e cientificistas, tal como pudemos ver na fala-práxis de Daniel Munduruku no primeiro capítulo desse texto. Para Ailton Krenak, portanto, o conhecimento e a publicização da diversidade cultural, epistemológica e política dos povos indígenas tem condições de servir-se da voz-práxis estético-literária como um caminho privilegiado que, dado seu sentido anti-paradigmático, anti-cientificista e anti-institucionalista, permite a expressão da própria singularidade e o relato autobiográfico da própria condição como diferença-alteridademinoria para além do formalismo, da neutralidade, da imparcialidade e da impessoalidade metodológico-axiológicas.

A voz-práxis estético-literária é, portanto, o próprio relato autobiográfico das diferenças-alteridades-minorias em termos de eu-nós lírico-político, que nos permite aceder diretamente àquela singularidade antropológicocultural e àquela condição de exclusão, de marginalização e de violência sofridas e vividas como minoria, como alteridade-diferença radical. Ela, a arte-literatura, em verdade, é a voz-práxis das vítimas por si mesmas e desde si mesmas, em seu sentido pungente, dramático, real, extremamente pessoal e comunitário-grupal. Ora, nós também identificamos uma umbilical ligação, uma projeção recíproca e uma mútua dependência entre o Movimento Indígena Brasileiro, do qual Ailton Krenak é um dos idealizadores e líderes, e a literatura indígena que se desenvolve ao longo desse período com uma intensidade cada vez mais impressionante: como se pode perceber na passagem acima, trata-se de, via voz-práxis estético-literária, publicizar e fomentar epistemológica, simbólica, cultural e politicamente a diversidade indígena, consolidando esses mesmos povos indígenas, em seu movimento e em seus/suas intelectuais, como sujeitos, práticas e valores públicopolíticos. Esse é o trabalho - hegemonia cultural e política - que deve ser construído epistemologicamente, simbolicamente, o trabalho ao qual o Movimento Indígena Brasileiro e seus/as intelectuais têm de assumir. Ailton Krenak chama essa situação, ou seja, a consolidação de uma vozpráxis público-política e da consequente hegemonia cultural, normativa e epistemológica do Movimento Indígena desde si mesmo e por si mesmo, de a segunda descoberta do Brasil. Senão vejamos:

Geralmente, quando os índios saíam na Manchete, era a fala do dono, os índios eram usados só para ilustrar. Tinha um grande jornalista da Manchete que ia em todos os Kuarup do Xingu, parecia o National Geographic, todos os Kuarup eram iguais, como se fossem um balé, um balé Bolshoi que se apresentava uma vez por ano. Ele era despersonalizado, qualquer sentido real que ele tivesse, que a vida das pessoas estava sendo cortada por uma estrada, que os índios estivessem morrendo de tuberculose, ou de gripe, surtando e morrendo lá na Escola Paulista de Medicina tentando salvar, não aparecia. Grupos inteiros, tribos que eram 130, 150 indivíduos foram reduzidas a 15 indivíduos, pior que uma guerra química. Então eles matavam aquele tanto de gente, as revistas davam as notícias pasteurizadas, parecia que era totalmente normal. Aí, quando essas pessoas começaram a ganhar voz, falar, apareceram coisas incríveis. Eu acho que teve uma descoberta do Brasil pelos brancos em 1500, e depois uma descoberta do Brasil pelos índios na década de 1970 e 1980. 
A que está valendo é a última. Os índios descobriram que, apesar de eles serem simbolicamente os donos do Brasil, eles não têm lugar nenhum para viver nesse país. Terão que fazer esse lugar existir dia a dia. Não é uma conquista pronta e feita. Vão ter que fazer isso dia a dia, e fazer isso expressando sua visão do mundo, sua potência como seres humanos, sua pluralidade, sua vontade de ser e viver (KRENAK, 2015, p. 247-248).

Ora, é essa construção do próprio lugar, em termos público-políticos, como hegemonia simbólica, epistemológica e cultural, que o Movimento Indígena de um modo geral e seu instrumento fundamental, a voz-práxis estético-literária em particular, têm de assumir e dinamizar, o que implica em que os povos indígenas falem por si mesmos e desde si mesmos na esfera pública e politicamente, esteticamente. A segunda descoberta do Brasil, portanto, é uma construção política, cultural e epistemológica dos povos indígenas por si mesmos e desde si mesmos (isto é, a partir de sua singularidade antropológico-cultural e de sua condição como minoria silenciada, excluída e marginalizada), cuja hegemonia, cujo caminho pode ser viabilizado pela e em termos da voz-práxis estético-literária - uma causa, uma condição e um caminho que, conforme estamos argumentando nesse texto, são assumidos em cheio pela literatura indígena brasileira em seus/suas escritores/as. É nesse sentido que a literatura indígena se transforma em uma voz-práxis política-politizante, carnal e vinculada, ligada diretamente ao Movimento Indígena e à causa indígena, e deles promotora.

Ao possibilitar a autoexpressão e a autoafirmação desde si mesmo e por si mesmo, nessa correlação de um eu-nós lírico-político ativista e militante, a literatura indígena traz para a esfera pública a própria fala-práxis dos indígenas, sem mediações, institucionalismos, tecnicismos e cientificismos, apresentando um/a escritor/a engajado que trabalha a partir da tradição ancestral e da pertença comunitário-grupal como base de sua vinculação público-política, promovendo-a, protegendo-a. Por isso mesmo, conforme estamos argumentando ao longo do texto, a literatura indígena, situada nesse grande campo epistemológico, político e normativo próprio às e aberto pelas manifestações estético-literárias das minorias (por elas mesmas e desde si mesmas, em termos de engajamento, politização e resistência), tem nesse sentido ativista e militante seu fecho de abóboda, sua pedra angular, no sentido de que direciona a produção-manifestação estético-literária à causa indígena, como Movimento Indígena, assumindo uma perspectiva política-politizante, carnal e vinculada que se define desde o início como engajamento profundo e pungente, deliberado e radical. Vejamos, no que diz respeito a isso, uma afirmação importantíssima de Daniel Munduruku:

A literatura é mesmo uma invenção incrível. Ela é uma espécie de evolução da própria escrita alfabética. Não sei explicar direito. 0 que sei é que ela vira um instrumento que orienta, igual à bussola num navio. Nem mesmo sei se ela é capaz de mudar o mundo. Sei, com certeza, que ela é capaz de mudar pensamentos errados, estereótipos, preconceitos. Ela aproxima mundos, constrói pontes, gera elos, amarra sonhos. Faz despontar horizontes. Ela é mágica.

Digo isso porque descobri na literatura uma grande aliada, grande companheira. Como contador de histórias ou como professor, minha tarefa seria bastante limitada, porque ficaria presa junto ao meu corpo, com a impossibilidade de estar em tantos outros lugares. Eu sempre imaginei atingir o maior número possível de pessoas. Assim, eu levaria a mensagem de nossa diversidade, de nossas culturas. Ainda que minha fala ganhasse contornos televisivos - coisa que nunca alimentei -, ela ficaria limitada aos formatos audiovisuais. A televisão é muito objetiva e dá pouca margem para mexer com a fantasia das crianças. Além do mais, não me sentia um astro de televisão para fazer programas que permitissem formar a consciência das pessoas. E será que deixariam eu fazer isso?

0 fato é que a literatura apareceu como uma aliada à altura. Sem pretensão, ela foi fazendo parte da minha vida e eu, como sempre, deixeime levar acreditando que também ali havia as mãos dos ancestrais. Foi assim que virei escritor. Mas também não me parecia completo. Nascido numa sociedade em que o coletivo é sempre mais importante que o individual, achei que precisava coletivizar essa ação para não parecer que a literatura seria para mim apenas um ganha-pão. Nunca pensei assim, e por isso passei a organizar os encontros de escritores e artistas indígenas. 
A ideia era fundar um núcleo capaz de atuar para influenciar a sociedade brasileira. Com isso, cumpriria minha função social com o Brasil e com o meu povo indígena (MUNDURUKU, 2017, p. 189-190).

Essa literatura engajada, militante e ativista liga-se, amalgama-se diretamente ao Movimento Indígena, vale dizer, ela permite a afirmação do sentido político-politizante, carnal e vinculado da voz-práxis das minorias desde si mesmas e por si mesmas, em nosso caso dos povos e dos/as escritores/as indígenas por si mesmos/as e desde si mesmos/ as. Ela representa uma perspectiva epistemológico-política em que as vítimas-minorias, as diferenças-alteridades biografam-se, apresentando-se direta e explicitamente em sua singularidade antropológico-comunitária e contando-nos de suas experiências e de sua condição de exclusão, de marginalização e de violência vividas e sofridas. Por meio da voz-práxis estético-literária enquanto ativismo, militância e engajamento, enquanto perspectiva política-politizante, carnal e vinculada, portanto, as minorias de um modo geral e os povos indígenas em particular contam-nos diretamente a sua dor, publicizam na correlação do eu-nós lírico-político suas riquezas, seus anseios e suas dores enquanto pessoas de carne e osso, enquanto comunidade-grupo que vive, ama, sente, anseia, mostrando-se iguais a nós e, ao mesmo tempo, irredutivelmente diferentes, singulares.

Sobretudo, por meio da voz-práxis estético-literária e sob a forma de voz-práxis estético-literária, os povos indígenas e seus/suas escritores/as rompem com o silenciamento, a invisibilização e o privatismo apolíticos e despolitizados-despolitizadores aos quais foram confinados em termos sociais, culturais, políticos, epistemológicos e paradigmáticos, assumindo-se como sujeitos epistemológico-políticos, como artífices criadores de sua história, da segunda descoberta do Brasil, nas palavras de Ailton Krenak, expressando-se e à sua pertença e à sua tradição ancestral-comunitárias em termos de um eu-nós lírico-político engajado, carnal, vinculado, para o qual a pertença ao grupo e à comunidade, à minoria em questão, é o ponto de partida e a base epistemológico-política da práxis, como práxis de crítica, resistência e luta. Nesse aspecto, como pudemos ver nas palavras de Ailton Krenak e de Daniel Munduruku citadas acima, a arte e a literatura permitem aos povos indígenas tanto a autoexpressão desde sua pertença antropológicocultural, a autoafirmação dessa sua singularidade antropológico-cultural e o desvelamento, a crítica e a publicização de sua condição de exclusão, de marginalização e de violência quanto a universalização da causa indígena, do Movimento Indígena, nacional e internacionalmente, que passa a se inserir na cultura, na política, na educação e na esfera pública cotidianas.

$\mathrm{Na}$ arte e na literatura, por conseguinte, as vítimas falam por si mesmas e desde si mesmas, de modo informal, carnal, politizante e vinculado, e seu drama aparece nu, cru e puro, totalmente autêntico, posto que não mediado, irrepresentável que ele é. Na arte e na literatura, as diferençasalteridades podem ser exatamente isso e partir disso, a saber, diferençasalteridades, posto que, aqui, na arte-literatura e sob a forma de voz-práxis estético-literária, não há base paradigmática unidimensional, massificadora, formal, tecnicista, mas apenas a própria autoexpressão desde a diferençaalteridade que se é, o biografar das próprias experiências que se tem, das alegrias e das dores que se vive. Aqui, o engajamento, o ativismo e a militância do eu-nós lírico-político como pertença, expressão, afirmação e publicização de uma minoria por si mesma e desde si mesma é o único critério orientador, o único princípio epistemológico-político ao qual a voz-práxis das diferenças-alteridades se remete e no qual se embasa, se dinamiza. Desse modo, as minorias constroem uma voz-práxis estéticoliterária, elas fazem arte-literatura para politizar sua causa, para politizarse e publicizar-se, rompendo com o silenciamento e o privatismo a elas impostos, tornando-se, em consequência, sujeitos epistemológico-políticos e movimento sociocultural públicos. É ainda Daniel Munduruku quem nos 
fala acerca da literatura indígena como engajamento, militância e ativismo no e como Movimento Indígena e enquanto autoexpressão, autoafirmação, resistência e luta público-políticas de uma minoria por si mesma e desde si mesma:

No começo não foi fácil, como tudo que se inicia. Educar a sociedade brasileira para que veja com outros olhos sua diversidade ancestral é uma jornada dura, difícil. Requer constância, confiança, fé. Não é um passe de mágica, mas um exercício de perseverança. Especialmente quando se lida com uma história que vem sendo construída há muitos séculos. Uma história contada a partir de um ponto de vista. História centrada numa visão economicista do mundo e também numa visão religiosa em que uns são criaturas de um Deus todo-poderoso e outros nada são. História que nega as histórias dos outros povos, das outras gentes. Essa história eurocêntrica foi forjada junto com a sociedade brasileira. Nesse novo povo não cabia a ancestralidade indígena, apenas a europeia. Os ancestrais da terra deviam ser esquecidos, excluídos, exterminados, deletados, para que nascesse um país novo. 0 resultado desse olhar foi a perseguição implacável contra os naturais da terra e contra suas espiritualidades, consideradas "coisas do demônio".

Nosso trabalho, portanto, não é nada fácil. Exige que a gente compreenda bem a narrativa engendrada na sociedade. Exige que a gente entenda a sociedade sem se preocupar se a sociedade nos compreende bem. A tarefa que nos propomos é reeducar as novas gerações de brasileiros para que consigam nos olhar com a dignidade que merecemos. Para isso, não podemos fazer um enfrentamento violento como nos tempos antigos, mas usar das mesmas armas que foram utilizadas para estabelecer seu preconceito: a escrita e a literatura. Por meio delas, inventaram rivalidades, criaram guerras de extermínio, difundiram estereótipos e, principalmente, dividiram-nos para poderem dominar nossos saberes ancestrais.

A literatura é, para nós, uma forma de atualizar nossos conhecimentos antigos. Por intermédio dela, pretendemos desconstruir a imagem negativa que fizeram de nós e mostrar que somos parte da aventura de ser brasileiros, ainda que tenhamos diferenças em nossa compreensão de humanidade. [...] É isso que procuramos manter vivo nos livros que escrevemos, nos filmes que produzimos, nas músicas que compomos, nos cantos que dançamos, nas universidades que freqüentamos. Atualizar nossos saberes ancestrais usando os equipamentos que a sociedade dita civilizada criou é nossa maneira de mostrar que não somos seres do passado, muito menos do futuro. Essa atualização mostra que estamos na Terra para ficar e queremos ensinar nossa maneira de manter o planeta vivo, queremos gritar para o mundo todo que somos parte e que ainda dá tempo de reverter o quadro vermelho de sangue que foi pintado ao longo de nossa história. Ainda dá tempo (MUNDURUKU, 2016, p.191-193).

Percebamos, mais uma vez, esse sentido ativista, militante e engajado da literatura de minorias de um modo geral e, em nosso caso, da literatura indígena brasileira em particular. Nas palavras de seus/suas intelectuais, dos/as quais pudemos ler algumas passagens nesse artigo, compreendemos que o eu-nós lírico-político não apenas não separa comunidade-grupo e indivíduo, não tornando o eu independente da comunidade ou do grupo de que ele/ela faz parte, senão que constrói uma mútua projeção e uma interdependência e um sustento recíprocos entre comunidade-grupo e indivíduo, de modo que esse eu-nós lírico-político adquire sentido por causa de sua pertença, de sua vinculação e de seu compromisso para com a comunidade-grupo de que emerge, de que faz parte como minoria. Em se tratando das minorias, como procuramos ressaltar ao longo do texto, essa é a conditio sine qua non e esse é o mote e o princípio orientadores da construção e da vinculação público-política de sua voz-práxis estéticoliterária, não havendo outro substitutivo para essa mesma voz-práxis ativista, militante e engajada, política-politizante, carnal e vinculada.

Como ressaltou de modo muito pungente Daniel Munduruku, a literatura indígena entra em cena como expressão de uma comunidade ou de um grupo, de uma minoria que possui especificidades antropológico-cultural e valores epistemológico-políticos próprios e que vivencia, enquanto minoria, enquanto diferença-alteridade, uma situação-condição de marginalização, de exclusão e de violência. Nesse caso, os povos indígenas, nas figuras de seus/suas intelectuais, passam a utilizar-se da escrita formal, das mídias digitais e, conforme nosso argumento, da literatura indígena exatamente 
para romper o silenciamento, a invisibilização e o privatismo aos quais esses mesmos povos e sua causa foram relegados e confinados ao longo de sua história, assumindo a literatura, assim, diretamente como ativismo, militância e engajamento de um eu-nós lírico-político carnal e vinculado - é uma voz-práxis estético-literária que tem uma base, a tradição ancestral e comunitária; um escopo, a politização e a publicização da condição indígena; e um método, o engajamento, o ativismo e a militância como forma de crítica social, resistência cultural e luta política. Ora, é desse modo que emerge mais uma característica fundamental dessa mesma literatura indígena, como seu núcleo constitutivo-normativo e sua dinâmica epistemológicopolítica e metodológico-programática, que consiste em um movimento a partir do qual e pelo qual a voz-práxis estético-literária indígena enquanto ativismo, engajamento e militância parte exatamente da pertença culturalcomunitária e da tradição ancestral e transforma-se em crítica do presente, de modo que essa pertença cultural-comunitária e essa tradição ancestral tornam-se crítica do presente, embasando o eu-nós lírico-político em termos desse ativismo, militância e engajamento (cf. MUNDURUKU, 2017, p. 113-128; THIÉL, 2012, p. 102-134; ALMEIDA, 2009, p. 85-122).

Como estamos argumentando, é por causa da vinculação umbilical com a comunidade-grupo-tradição de origem-pertença enquanto diferençaalteridade-minoria radical que os/as intelectuais indígenas transformam sua literatura em baluarte de defesa e de promoção do Movimento Indígena, assumindo uma postura de retomada, de valorização e de utilização das bases antropológico-ontológicas, socioculturais e epistemológico-políticas comunitárias como núcleo, fundamento e dinâmica de seu criticismo social, de sua resistência cultural e de sua luta política. Nesse sentido, se os/as indígenas rompem o silenciamento e o privatismo apolíticos e despolitizados-despolitizadores, se eles/elas assumem-se como movimento e sujeitos epistemológico-políticos públicos e publicizados, a razão é bem clara: sua tradição cultural-comunitária-grupal-ancestral os/as impulsiona a isso, os/as embasa nessa práxis público-política. Sobre isso, sobre a pertença comunitária e a tradição ancestral como base da e mote para a crítica do presente, vejamos a instigante reflexão de Davi Kopenawa, apresentada n'A queda do céu: palavras de um xamã yanomami:

Alguém só se torna xamã mesmo quando o espírito de Omama desce até ele. Sem isso, os outros xapiri não teriam vontade de se aproximar dos jovens novatos. Mas quando a imagem de Omama manda na frente as mulheres espíritos, de quem é pai e sogro, todos os outros xapiri, apaixonados, saem correndo atrás delas, para dançar e construir com alegria sua casa. Foi o que aconteceu quando meu sogro me fez beber yãkoana pela primeira vez. Fiquei logo em estado de fantasma. Tinha tomado tanto pó que já estava a ponto de virar outro. Tinha morrido sob o efeito do sopro dos xapiri que os xamãs mais velhos tinham me dado com o seu pó de yãkoana. Foi nesse momento que a imagem de Omama se revelou a mim. Então, logo eu mesmo me tornei espírito, como seu filho, antigamente. Assim é. Se não viramos outro com o pó de yãkoana, só podemos viver na ignorância. Passamos então o tempo só comendo, rindo, copulando, falando à toa e dormindo sem sonhar muito. Sem o poder da yãkoana, as pessoas não se perguntam sobre as coisas do primeiro tempo. Nunca pensam: "Quem eram mesmo nossos ancestrais que viraram animais? Como foi que o céu caiu antigamente? De que modo Omama criou a floresta? 0 que dizem mesmo os cantos e as palavras dos xapiri?". Ao contrário, quando bebemos o pó de yãkoana como Omama nos ensinou a fazer, nossos pensamentos nunca ficam ocos. Podem crescer, caminhar e se multiplicar ao longe, em todas as direções. Para nós, esse é o verdadeiro modo de conseguir sabedoria.

Apesar de tudo isso, os brancos já nos ameaçaram muitas vezes para nos obrigar a abandonar os xapiri. Nessas ocasiões, só sabiam dizer: "Seus espíritos estão mentindo! São fracos e estão enganando vocês! São de Satanás!". No começo, quando eu ainda era muito jovem, tinha medo da fala desses forasteiros e, por causa dela, cheguei a duvidar dos xapiri. Por algum tempo, me deixei enganar por essas más palavras e até tentei, com muito esforço, responder às palavras de Teosi. Mas isso acabou mesmol Faz muito tempo que eu não deixo mais as mentiras dos brancos me confundirem e que não me pergunto mais: "Por que eu não tento virar um deles?". Tornei-me homem, meus filhos cresceram e tiveram seus próprios 
filhos. Agora, nunca mais quero ouvir más palavras sobre os xapiri! Omama os criou depois de ter desenhado nossa floresta e, desde então, eles continuaram cuidando de nós. Eles são muito valentes e muito bonitos. Seus cantos fazem nossos pensamentos aumentar em todas as direções e ficar firmes. E por isso vamos continuar fazendo dançar suas imagens e defendendo suas casas, enquanto estivermos vivos. Somos habitantes da floresta. É esse o nosso modo de ser e são estas as palavras que quero fazer os brancos entenderem (KOPENAWA; ALBERT, 2015, p. 510-511).

Note-se, na voz-práxis de Davi Kopenawa, dois pontos fundamentais, que constituem e dinamizam seu relato autobiográfico enquanto literatura indígena: primeiramente, o estilo literário e o movimento epistemológicopolítico que vão da autoexpressão e da autoafirmação identitárias à crítica do presente, onde a situação atual é correlacionada, atrelada, enquadrada e comparada ao passado, à tradição ancestral-comunitária, e onde esta é colocada no mesmo plano daquela, como um fato atual, ligado à condição, às potencialidades e aos desafios próprios aos povos indígenas; em segundo lugar e como consequência, o fato de que a crítica do presente é possível porque está fundada exatamente na singularidade antropológica, cultural e comunitária, na tradição ancestral que constitui cada povo indígena e os povos indígenas como um todo, de modo que é exatamente a pertença cultural-comunitária e a tradição ancestral e xamânica que se constituem como crítica do presente, resistência cultural e luta política. Essa é a característica mais fundamental do eu-nós lírico-político indígena, que define a sua expressão estético-literária como ativismo, militância e engajamento do/a escritor/a e sua ligação e dependência umbilicais para com o grupo e a comunidade, para com o Movimento Indígena.

Nesse sentido, pode-se argumentar que (a) a permanente remissão à pertença comunitária e à tradição ancestral definem a autoexpressão e a autoafirmação do eu-nós lírico-político indígena; (b) a correlação e a dependência inextricáveis entre comunidade-grupo e indivíduo são a base, o mote e o caminho da voz-práxis estético-literária como ativismo, militância e engajamento dos/as indígenas por si mesmos/as e desde si mesmos/as; (c) a crítica do presente é fundada na e dependente da pertença cultural-comunitária e da tradição ancestral-xamânica, que singularizam a minoria indígena e, ao fim e ao cabo, explicitam a sua própria condição de marginalização, de exclusão e de violência por causa daquela singularidade; e (d), por fim, a voz-práxis estético-literária indígena constrói e estiliza de modo concomitante um movimento de autoexpressão e autoafirmação culturais, comunitárias e identitárias e, por causa e a partir disso, transforma-se em crítica social, resistência cultural e luta política em nome do Movimento Indígena e a favor da causa indígena em termos de esfera público-política ${ }^{5}$. Em tudo isso, o grupo-comunidade torna-se central, de modo a imbricar-se indelevelmente história e pertença comunitárias e destino individual. Diz Eliane Potiguara, em seu poema "Identidade indígena":

Nosso ancestral dizia: Temos vida longa!/Mas caio da vida e da morte/ E range o armamento contra nós./Mas enquanto eu tiver o coração aceso/Não morre a indígena em mim/ E nem tampouco o compromisso que assumi/Perante os mortos/De caminhar com minha gente passo a passo/E firme, em direção ao sol./ Sou uma agulha que ferve no meio do palheiro/ Carrego o peso da família espoliada/Desacreditada, humilhada/ Sem forma, sem brilho, sem fama (POTIGUARA, 2004, p. 102-103).

Note-se a expressão dinamizadora dessa fala-práxis, representativa, conforme estamos argumentando, da literatura de minorias de um modo geral e da literatura indígena em particular: o eu-nós lírico-político carrega o peso, a dor e a herança da família espoliada, marginalizada

5 Como diz Graça Graúna, “[...] apesar da intromissão dos valores dominantes, o jeito de ser e de viver dos povos indígenas vence o tempo: a tradicão literária (oral, escrita, individual, coletiva, híbrida, plural) é uma prova dessa resistência" (GRAÚNA, 2013, p.15). 
e excluída, partindo da autoexpressão e da autoafirmação identitárias, da pertença cultural e da tradição ancestral-xamânica, passando pela denúncia da exclusão, da marginalização e da violência vividas e sofridas e transformando-se direta e pungentemente em crítica social, resistência cultural e luta política, via ativismo, engajamento e militância políticopolitizantes, carnais e vinculados ao Movimento Indígena. O eu-nós lírico-político não é voyeurista, sem vínculos e sobreposto à pertença cultural-comunitária e à dependência ancestral-xamânica, senão que tem exatamente nessa pertença cultural-comunitária e nessa dependência ancestral-xamânica sua base, seu caminho e seu norte epistemológicopolíticos - ele/ela é escritor/a de minorias, sua voz-práxis é própria a uma minoria, e assim sempre será, a ela sempre pertencerá. Nesse sentido, ao eu-nós lírico-político indígena (e ao eu-nós lírico-político de minorias, como minoria) não cabe a descrição dada por Walter Benjamin relativamente à autoria e ao romance modernos, marcados por uma subjetividade absoluta, autorreferencial, voyeurista e desengajada de sua comunidade-grupo, o que torna a autoria e o romance em diletantismo apolítico no mais das vezes. Conforme Walter Benjamin,

Podemos fazer uma travessia marítima e cruzar o oceano, sem terra à vista, vendo unicamente o céu e o mar. É o que faz o romancista. Ele é o mudo, o solitário. [...] 0 romancista se separou do povo e do que ele faz. A matriz do romance é o indivíduo em sua solidão, o homem que não pode mais falar exemplarmente sobre suas preocupações, a quem ninguém pode dar conselhos, e que não sabe dar conselhos a ninguém. Escrever um romance significa descrever a existência humana, levando o incomensurável ao paroxismo (BENJAMIN, 1987, p. 59).

A subjetividade absoluta, voyeurista e desvinculada relativamente ao grupo de que emerge e que a identifica, tal como essa descrição de Walter Benjamin acerca do autor e do romance modernos, não se enquadra em absoluto na voz-práxis estético-literária das minorias de um modo geral e em termos de autoria indígena em particular, uma vez que, nestas, o eu-nós lírico-político depende fundamentalmente da e se enraíza inextricavelmente na pertença comunitário-grupal, na singularidade antropológico-cultural e na condição epistemológico-política como minoria, como vítima, como alteridade-diferença radical. Conforme a voz-práxis de Eliane Potiguara, o eu-nós lírico-político assume a herança e a pertença cultural-comunitária-grupal como seu horizonte simbólico, normativo e antropológico e compromete-se com a promoção e a defesa dela, assim como se posiciona política e publicamente em termos de denúncia e de combate da marginalização, da exclusão e da violência vividas e sofridas como minoria. Ora, é somente nessa dinâmica que vai da comunidade ao indivíduo e que retorna do indivíduo à comunidade, que parte da tradição e da pertença culturais, comunitárias e xamânicas, da tradição ancestral, passa pela denúncia e pela publicização da opressão e da marginalização e transforma-se em crítica do presente, isto é, somente por causa do ativismo, da militância e do engajamento no e como movimento indígena, que efetivamente faz sentido falarmos e enquadrarmos teórica e politicamente a voz-práxis indígena em termos estético-literários (cf. BANIWA, 2006, p.56-85; GRAÚNA, 2013, p.43-93; ALMEIDA; QUEIROZ, 2004, p. 121-168).

Nesse sentido, se a construção dessa mesma literatura indígena não pode ser outra coisa que ativismo, militância e engajamento ao Movimento Indígena por parte do eu-nós lírico-político, se a autoexpressão e a autoafirmação comunitárias embasam a e colocam-se como crítica do presente via voz-práxis estético-literária indígena direta, da mesma forma a sua recepção não pode ser dissociada da própria pertença comunitária, da própria condição de e como minoria e, assim, não pode ser outra coisa que não politização abrangente, direta e radical da voz-práxis, da 
obra-práxis. Esse, aliás, é o apelo e o convite que as minorias nos fazem desesperadamente, que os/as indígenas nos trazem em termos de esfera público-política - e essa é a condição de sua resistência, de sua sobrevivência, de seu florescimento, ou seja, a politização radical, o ativismo, a militância e o engajamento como minoria, como Movimento Indígena brasileiro e em termos de esfera público-política, como publicização, desvelamento, crítica e promoção da própria singularidade antropológica e da própria condição epistemológico-política enquanto minoria.

\section{Considerações finais}

À guisa de conclusão, queremos salientar brevemente o núcleo desse nosso artigo, que consistiu na defesa de que a literatura de minorias de um modo geral e a literatura indígena brasileira em particular são marcadas por uma voz-práxis ativista, militante e engajada em que o eu-nós líricopolítico parte da autoexpressão e da autoafirmação comunitárias, passa pelo desvelamento e pela denúncia da exclusão, da marginalização e da violência vividas e sofridas enquanto minoria e, com isso, por meio da utilização da tradição ancestral-xamânica e dessa pertença comunitária-grupal, dessa constituição e dessa vinculação umbilicais como minoria, como alteridadediferença, com suas experiências e seus relatos da marginalização, da exclusão e da violência vividas e sofridas, assume-se e dinamiza-se como crítica do presente, resistência cultural e luta política. Esse é o sentido e essa é a dinâmica da obra-práxis produzida e publicizada pelas minorias, desde si mesmas, de sua condição política como minorias, de modo que ela não pode ser outra coisa que politização radical, direta e abrangente, em que os excluídos e os marginalizados falam-agem por si mesmos, como diferençasalteridades, e desde sua condição de vítimas, de oprimidos e marginalizados. E esse é o sentido e essa é a dinâmica dos posicionamentos público-políticos dos/as intelectuais de minorias, dos/as intelectuais indígenas, que, por explicitarem e assumirem a causa do seu grupo, a causa do Movimento Indígena, transformam-se em sujeitos políticos e politizantes, carnais e vinculados, os quais não podem ser compreendidos sem a referência à sua origem antropológica, à sua comunidade-grupo, à sua tradição ancestralxamânica e, assim, à sua condição política como minoria.

\section{Referências}

ALMEIDA, Maria Inês de. Desocidentada: experiência literária em terra indígena. Belo Horizonte: Editora UFMG, 2009.

ALMEIDA, Maria Inês de; QUEIROZ, Sônia. Na captura da voz: as edições da narrativa oral no Brasil. Belo Horizonte: Autêntica, 2004.

BANIWA, Gersem dos Santos Luciano. $O$ índio brasileiro: o que você precisa saber sobre os povos indígenas no Brasil de hoje. Brasília: Ministério da Educação, Secretaria de Educação Continuada, Alfabetização e Diversidade; LACED/Museu Nacional, 2006.

BHABHA, Homi. O local da cultura. Belo Horizonte: Editora da UFMG, 1998.

BENJAMIN, Walter. Magia e técnica, arte e política. São Paulo: Brasiliense, 1987.

BUTLER, Judith. Problemas de gênero: feminismo e subversão da identidade. Rio de Janeiro: Civilização Brasileira, 2003.

CHAKRABARTY, Dipesh. Provincializing Europe. Princeton: Princeton University Press, 2000.

CHAKRABARTY, Dipesh. Habitations of modernity: essays in the wake of subaltern studies. Chicago: University of Chicago Press, 2002.

DALCASTAGNÈ, Regina. Literatura brasileira contemporânea: um território contestado. Vinhedo: Horizonte, 2012.

DANNER, Leno Francisco; DORRICO PERES, Julie. A literatura indígena como crítica da modernidade: sobre xamanismo, normatividade e universalismo - notas desde 'A queda do céu: palavras de um xamã yanomami', de Davi Kopenawa e Bruce Albert, $O$ Eixo e a Roda, UFMG, Belo Horizonte, v. 26, n. 03, 2017, p. 129-156. 
DANNER, Leno Francisco; BAVARESCO, Agemir; DANNER, Fernando. A estética das minorias contra a correlação de institucionalismo forte, cientificismo e tecnicalidade: sobre a voz-práxis das minorias como arte-literatura, Clareira - Revista de Filosofia da Região Amazônica, Porto Velho (R0) v. 4, n. 1, 2017, p. 15-48.

DUSSEL, Enrique. 1492, o encobrimento do outro: a origem do mito da modernidade. Petrópolis: Vozes, 1993.

FANON, Franz. Os condenados da Terra. Rio de Janeiro: Civilização Brasileira, 1968.

GRAÚNA, Graça. Contrapontos de literatura indígena contemporânea no Brasil. Belo Horizonte: Mazza Edições, 2013.

HABERMAS, Jürgen. A inclusão do outro: estudos de teoria política. São Paulo: Loyola, 2002.

HONNETH, Axel. Luta por reconhecimento: a gramática moral dos conflitos sociais. São Paulo: Editora 34, 2003.

HONNETH, Axel. Reificación: un estudio en la teoría del reconocimiento. Buenos Aires: Katz, 2007.

KOPENAWA, Davi; ALBERT, Bruce. A queda do céu: palavras de um xamã yanomami. São Paulo: Companhia das Letras, 2015.

KRENAK, Ailton. Encontros. Rio de Janeiro: Azougue, 2015.

MBEMBE, Achille. On the postcolony. Berkeley and Los Angeles: University of California Press, 2001

MBEMBE, Achille. Crítica da razão negra. Lisboa: Antígona, 2014.

MIGNOLO, Walter D. La idea de América latina: la herida colonial y la opción decolonial. Barcelona: Editorial Gedisa, 2007.

MUNDURUKU, Daniel. O caráter educativo do movimento indígena brasileiro (19701990). São Paulo: Paulinas, 2012.

MUNDURUKU, Daniel. Memórias de índio: uma quase autobiografia. Porto Alegre: Edelbra, 2016

MUNDURUKU, Daniel. Mundurukando II: roda de conversa com educadores. Lorena: UK'A Editorial, 2017.

MUNDURUKU, Daniel. Visões de ontem, hoje e amanhã: é hora de ler as palavras. In: POTIGUARA, Eliane. Metade cara, metade máscara. São Paulo: Global, 2004, p. 15-16.
POTIGUARA, Eliane. Metade cara, metade máscara. São Paulo: Global, 2004

QUIJANO, Aníbal. Colonialidad y modernidad/racionalidad, Perú Indig., Lima, v. 13 n. 29, p. 11-20, 1992.

SPIVAK, Gayatri C. Pode o Subalterno Falar? Belo Horizonte: Editora da UFMG, 2010

THIÉL, Janice. Pele silenciosa, pele sonora: a literatura indígena brasileira em destaque. Belo Horizonte: Autêntica, 2012.

\section{Texto disponível na Internet:}

GRAÚNA, Graça. "Escrevivência indígena”. In: Blog Graça Graúna, 28 set. 2017. Disponível em: <http://ggrauna.blogspot.com/2017/09/escrevivencia-indigena.html>. Acesso em: 10 ago. 2018.

Recebido em 28/05/2018,

Aceito em 10/08/2018. 